\author{
Oksana Yakymchuk \\ National Pedagogical Dragomanov University (Kyiv, Ukraine) \\ https://orcid.org/oooo-ooo3-2358-5622 \\ e-mail: yakymchuk-o@ukr.net
}

\title{
EDUCATION REFORM: PHILOSOPHY, METHODOLOGY, PRACTICE
}

\section{Abstract}

The first steps in reforming education after the declaration of independence, provided by the State National Program «Education» («Ukraine of the XXI century»), revealed the first contradictions, the overcoming of which required a new philosophy and methodology reform activities. Their contours for a ten-year period of state-building processes, defined by the Decree of the President of Ukraine «On urgent measures to ensure functioning and development of education in Ukraine » (2005) turned out to be quite contradictory. On the one hand, the ideas of integration of our state into the European one were actively implemented educational space. On the other hand, the reform processes that began to slow down began in the first half of the first decade of the new century. How could such contradictory tendencies be combined and what did it eventually lead to in the context of the qualitative growth of Ukrainian education? The research is devoted to this problem, set out in this article.

Education researchers emphasize the timeliness and the need to modernize education, brought to life by the Bologna Process, which opens the possibility of building an innovative model of higher education that would be able not only to adequately respond to the challenges of the time, but also to work for the future, while expressing the need for a harmonious mix of European innovation traditions. After joining the Bologna Declaration, Ukrainian educators not only became acquainted with the concepts developed within the framework of the Bologna Process, which are aimed at improving the quality of education, but also witnessed and participated in real reforms. Although there are some difficulties and contradictions, among which the uncertainty of the prospects and principles of relations between Ukraine and the EU plays an important role. Prospects for further research are in the field of building fruitful cooperation between educators of Ukraine and the EU in the so-called post-Bologna process.

Key words: education reform, European integration in the field of education, Lisbon Declaration, Bologna Process 


\section{Якимчук Оксана Іванівна}

Національний педагогічний університет імені М. П. Драгоманова (м. Київ, Україна)

https://orcid.org/oooo-ooo3-2358-5622

e-mail: yakymchuk-o@ukr.net

\section{РЕФОРМА ОСВІТИ: ФІЛОСОФІЯ, МЕТОДОЛОГІЯ, ПРАКТИКА}

\section{Резюме}

Перші кроки реформування освіти після проголошення незалежності, передбачені Державною національною програмою «Освіта» («Україна XXI століття), виявили перші суперечності, подолання яких потребували нової філософії та методології реформаторської діяльності. Їх контури на десятирічний період державотворчих процесів, визначені Указом Президента України «Про невідкладні заходи щодо забезпечення функціонування та розвитку освіти в Україні» (2005 р. ) виявилися доволі суперечливими. 3 одного боку, активно впроваджувалися ідеї інтеграції нашої держави в європейський освітній простір, з іншого-почали гальмуватися ті реформаторські процеси, що розпочалися в першій половині першого десятиліття нового століття. Як могли поєднуватися такі суперечливі тенденції і до чого це зрештою призвело в контексті якісного зростання української освіти? Саме цій проблемі присвячене дослідження, викладене в даній статті.

Мета статті - проаналізувати основні параметри реформування освіти 32007 по 2015 рр., дослідити суперечливі тенденції реформаторських процесів освіти зазначених років.

Результати. Дослідники освіти наголошують на своєчасності і необхідності модернізації освіти, викликаною до життя Болонським процесом, що відкриває можливості розбудови інноваційної моделі вищої освіти, яка була б здатна не тільки адекватно реагувати на виклики часу, а й працювати на перспективу, висловлюючи при цьому думку про потребу гармонійного поєднання європейських нововведень і кращих вітчизняних традицій. Після приєднання до Болонської Декларації українські освітяни не лише 
ознайомились 3 розробленими в рамках Болонського процесу концепціями, що націлені на підвищення якості освіти, але стали свідками й учасниками реальних реформ. Хоча $є$ певні труднощі і суперечності, серед яких вагому роль відграє невизначеність перспектив та принципів взаємовідносин України та ЄC. Перспективи подальших наукових досліджень полягають саме в сфері розбудови плідної співпраці між освітянами України та ЄС в рамках так званого постболонського процесу.

Ключові слова: реформа освіти, європейська інтеграція в сфері освіти, Лісабонська декларація, болонський процес.

\section{Bcmyn}

Період української освітянської історії від 2007 до 2015 року навряд чи можна назвати провальним. Деякі позитивні результати були досягнуті. Однак, загалом національна система освіти, створена попередніми поколіннями реформаторів, скоріш руйнувалась, ніж розбудовувалась. Більшменш помітними позитиви розвитку освіти стали в період керівництва галуззю міністром I. Вакарчуком. Його наступники увійшли в історію, здебільшого, як її руйнівники.

Ключову роль в цей період відігравав Указ Президента України Віктора Ющенка «Про невідкладні заходи щодо забезпечення функціонування та розвитку освіти в Україні» (липень, 2005 р. ) [1], на виконання якого була спрямована вітчизняна освітня політика до 2010 року (протягом періоду президентства В. Ющенка). Оцінюючи значення згадуваного вище документу, підкреслимо, що саме у ньому були окреслені ключові напрями освітньої реформи послідуючих років.

Враховуючи перспективи інтеграції України до Європейського Союзу, підкреслюється в Указі, в державі має бути здійснена низка освітніх інновацій, головними серед яких є: розробка та затвердження програми роботи з обдарованою молоддю, що спрямована на створення в Україні сприятливих умов для пошуку, підтримки і стимулювання інтелектуально і творчо обдарованих дітей та молоді, самореалізації творчої особистості в сучасному суспільстві; забезпечення реалізації процесу інформатизації освіти, що передбачало завершення комп'ютеризації загальноосвітніх шкіл, забезпечення їх телекомунікаційними засобами виходу до міжнародної інформаційної мережі Інтернет; зміцнення демократичних засад в освіті, у тому числі шляхом розвитку учнівського і студентського самоврядування, залучення в установленому порядку дітей та молоді до участі у вирішенні питань місцевого значення; проведення вступних випробувань до вищих навчальних закладів шляхом зовнішнього незалежного оцінювання навчальних досягнень випускників навчальних закладів системи загальної середньої освіти; удосконалити процес прогнозування потреби суспільства в педагогічних кадрах; створення національної системи моніторингу якості 
освіти на основі критеріїв держав - членів Європейського Союзу та забезпечення участі загальноосвітніх навчальних закладів у міжнародних обстеженнях якості освіти; викорінення хабарництва; здійснення заходів, спрямованих на реалізацію в Україні положень Болонської декларації; радикальне поліпшення фінансування галузі [там же] тощо.

\section{Методи дослідження}

Методологічну основу філософсько-освітнього дослідження реформування освіти (2007-2015 pр. ) складають загальнонаукові принципи пізнання освітніх явищ, які підпорядковані історико-філософському, системно-структурному, конститутивному, синергетичному методам пізнання.

Методологічні рефлексії дискурсу філософії освіти висувають на перший план категорію реформування освіти, що обумовлює застосування постмодерністських принципів аналізу, які вносять низку позитивних елементів у розуміння освітньої діяльності та відповідальності за ії здійснення. Складність, непередбачуваність, відкритість сучасних світових тенденцій розвитку освіти обумовлює необхідність включення в осмислення освітнього процесу синергетичного підходу, адекватного сучасній методологічній культурі мислення.

\section{Результати дослідження}

Серед означених вище напрямків були реалізовані передусім заходи із впровадження зовнішнього незалежного оцінювання випускників (далі 3НО), які виявили бажання вступати до вищих навчальних закладів. Хоча ідея ЗНО навчальних досягнень випускників народилась ще на початку 1990-х й здобула розвиток на початку 2000-х, втім саме з прийняттям означеного вище указу пов'язують розгортання всеохоплюючого запровадження ЗНО в Україні.

Постанова КМУ № 1312 «Про невідкладні заходи щодо запровадження зовнішнього незалежного оцінювання та моніторингу якості освіти» від 31.12.2005 р. [13], що слідувала за Указом, унормувала цей процес. 3 цього періоду послідовно запроваджувались наступні кроки, спрямовані на забезпечення функціонування ЗНО: 1) створення відповідної інфраструктури: Український центр оцінювання якості освіти (УЦОЯО), регіональні центри оцінювання якості освіти, пункти тестування, лабораторії при Інститутах післядипломної педагогічної освіти тощо; 2) напрацювання технологій складання завдань для проведення зовнішнього оцінювання, удосконалення їхнього змісту, навчання педагогічних працівників щодо проведення тестування, безпосередньої організації процесу, а також перевірки результатів; 3) проведення інформаційних кампаній, спрямованих на роз'яснення населенню переваг і особливостей організації зовнішнього тестування [2, с.8]. Власне у 2005 році відбулось тестування 10030 учнів 
з 1567 шкіл України, а у 2008 році вступ до всіх українських ВНЗ, незалежно від їх підпорядкування та форми власності, здійснювався за результатами тестування, відображеними у сертифікатах. Як наслідок у 2009 році у ЗНО, що виконувало роль державної підсумкової атестації і сертифікації, взяв участь 433501 абітурієнт [там же, с. 12].

Не дивлячись на певні недоліки в організації ЗНО, які протягом багатьох років не вдається подолати, його важливість як для отримання об’єктивних даних про якість національної системи освіти, так і для сертифікації реального рівня розвитку кожного учня не викликає сумнівів. Аналіз досвіду вступної кампанії до українських ВНЗ засвідчує, що з введенням ЗНО відбулися позитивні зрушення в забезпеченні рівного доступу громадян до вищої освіти на засадах об'єктивності і справедливості. Багато фахівців розцінюють цю соціально важливу акцію як одну з плідних системних реформ української освіти [там же, с. 21]. Окрім впровадження ЗНО, активно розроблялись та впроваджувались заходи щодо реалізації в Україні положень Болонської декларації, значення якої у розвитку національній системи освіти розглянемо нижче.

Проте у сферах виховної роботи, підготовки педагогічних кадрів та фінансування галузі суттєвих змін не відбулось, що підтверджує Указ Президента № 244 «Про додаткові заходи щодо підвищення якості освіти в Україні» [3] від 20.03.2008. У цьому документі наголошується на необхідності удосконалення системи підготовки педагогічних працівників, поліпшення виховної роботи з дітьми, учнівською і студентською молоддю, зменшення негативних впливів на них соціального середовища, поліпшення умов навчання для дітей-сиріт, дітей, позбавлених батьківського піклування, та дітей з обмеженими фізичними можливостями, вживання заходів щодо підвищення соціального статусу педагогічних працівників, удосконалення порядку фінансування дошкільних і позашкільних навчальних закладів тощо.

Банально, але факт: теоретичні розвідки мають передувати практиці. На жаль, здавалося б такі зрозумілі для побутового мислення питання, як скажімо, фінансування галузі, виховна робота у вузі, боротьба з хабарництвом тощо, досі залишаються «відкритою книгою» для сучасної педагогічної теорії. Мало дослідженим з точки зору соціокультурної динаміки ціннісних орієнтацій, залишається студентство, особливо випускники вищих навчальних закладів. Їх світоглядна позиція в контексті отримання так званого «першого робочого місця» та «відпрацювання» за призначенням у наукових розвідках сучасних юнологів ледь проглядається.

У досліджувані нами роки зростає розрив між вищою освітою та ринком праці, освітянами та працедавцями. Так, щороку скорочувалась кількість випускників ВНЗ, які одержують направлення на роботу: якщо в 2004 р. цей показник становив 35,0\% від загальної кількості випускників 106 
BН3 III-IV рівнів акредитації, то в 2009 р. -30,4\%. Основні причини такої негативної тенденції полягали у невідповідності знань, умінь і навичок випускників вимогам працедавців; незакріпленості теоретичних знань студентів на практиці; невідповідності освітньо-професійної структури випускників запитам галузей економіки. Відсутність взаємодії роботодавців із закладами вищої освіти обмежує можливості працевлаштування випускників ВНЗ. Українські роботодавці не бажають інвестувати в освіту: доказом цього $є$ низький рівень оплати юридичними особами навчання студентів [4, с. 101-102].

Вирішення цих проблем пов'язувалось, передусім, з модернізацією та європеїзацією вітчизняної освіти. Тому зусилля теоретиків та практиків освіти передусім спрямовувались на реалізацію Україною європейського вибору через засоби освіти. Першим вагомим шляхом у цьому напрямку була ратифікація Україною Лісабонської конвенції про визнання кваліфікацій, які існують у системі вищої освіти Європи. Ця знаменна подія відбулась ще наприкінці 1999 року, коли Верховна Рада України ратифікувала «Конвенцію про визнання кваліфікацій з вищої освіти в Європейському регіоні» [5]. Розроблена і прийнята під егідою Ради Європи та ЮНЕСКО дана конвенція була підписана від імені України 11 квітня 1997 року в м. Лісабоні (Португалія). Окрім України цю конвенцію підписали ще 42 країни, більшість з яких згодом сформулювали і принципи Болонської декларації.

Оцінку значення Болонської декларації у розвитку національної системи освіти знаходимо у працях В. П. Андрущенка, М. З. Згуровського, В. С. Журавського, В. Г. Кременя, та ін. Підкреслюючи своєчасність і необхідність неминучої освітньої реформи, викликаною до життя Болонським процесом, усі вони та чи інакше висловлювали думку про потребу гармонійного поєднання європейських нововведень і кращих вітчизняних традицій.

Так, В. П. Андрущенко зазначав, що Болонський процес був лейтмотивом поточного десятиріччя (мається на увазі перше десятиріччя 2000-х) у розвитку освіти, закликаючи до глибоко дослідження таких питань як: запровадження кредитно-модульної системи, академічна мобільність викладачів та студентів, забезпечення рівного доступу громадян до якісної освіти, освіта протягом життя, взаємозв’язок системи «освіта-наукапрактика-виробництво» [6, с. 6]. При цьому В. П. Андрущенко зауважував, що універсалізація освітніх систем, стимульована Болонськими домовленостями, має свої межі. Адаптуючи освіту до рівня європейських стандартів, ми маємо розвивати власну освітянську національну традицію, зберігати й обстоювати «педагогічну матрицю» української освіти, вводити іiі надбання у європейський і світовий освітній простір [7, с. 17].

М. З. Згуровський оцінював Болонський процес як інструмент гармонізації нашої системи освіти з європейською, що вимагало вирішення 
глибоких, хоча й традиційних проблем [8]. Вони пов'язані з оновленням змісту освіти й з вдосконаленням її методології відповідно до суспільних і технологічних перетворень, які відбуваються як у нашій країні, так і в світі. «Якщо майбутнє України пов'язане з Європою, то не можна надалі стверджувати, що Болонський процес має для нас лише просвітнє та пізнавальне значення. Надання високої оцінки національній системі освіти не має заспокоювати нас і стримувати глибинне їі реформування» [там же].

Оцінюючи значення для України Болонської декларації та інших документів, що супроводжують Болонський процес, автори колективної монографії «Інтеграція в європейський освітній простір: здобутки, проблеми, перспективи» під редакцією В. Г. Ващука зазначають, що «входження України в цивілізоване світове співтовариство неможливе без структурної реформи національної системи вищої освіти, спрямованої на збереження мобільності, сприяння працевлаштуванню випускників на внутрішньому та зовнішньому ринках праці в умовах високої конкуренції. Метою модернізації вищої освіти в Україні є створення такої моделі освітнього процесу, в якій би оптимально поєдналися кращі вітчизняні й зарубіжні традиції. Поєднання гуманістичних традицій української педагогіки та зарубіжного досвіду виховання особистості, здатної до активних самостійних дій, дозволить створити динамічну, мобільну, конкурентоспроможну модель освітньої системи [4, с. 7-8].

Окрім необхідності сполучення вітчизняних традицій з впровадженням прогресивного європейського досвіду, майже усі дослідники вказують на головну перевагу так званої «болонізації» системи національної вищої освіти. Цією однозначною перевагою є сама необхідність реформ або навіть модернізації системи вищої освіти. Так, міністр освіти і науки України 2007-2010 pp. I. О. Вакарчук у своїй доповіді під час Парламентських слухань $з$ приводу підготовки нової редакції Закону України «Про вищу освіту», приєднання України до Болонського процесу оцінив в контексті необхідності «вибудувати структуру вищої освіти на європейських принципах, що дасть можливість вищій освіті стати зрозумілою для Європи, бути рівноправним членом Європейського простору вищої освіти - i в обов'язках, i в правах» [9].

\section{Висновки}

Отже, оцінюючи значення Болонської декларації у розвитку національної системи освіти, провідні дослідники освіти наголошували на своєчасності і необхідності модернізації освіти, викликаноюдо життя Болонським процесом, що відкриває можливості розбудови інноваційної моделі вищої освіти, яка була б здатна не тільки адекватно реагувати на виклики часу, а й працювати на перспективу, висловлюючи при цьому думку про потребу гармонійного поєднання європейських нововведень і кращих вітчизняних 
традицій. Дійсно, після приєднання до Болонської Декларації українські освітяни не лише ознайомились з розробленими в рамках Болонського процесу концепціями, що націлені на підвищення якості освіти, але стали свідками й учасниками реальних реформ. Хоча $є$ певні труднощі і суперечності, серед яких вагому роль відграє невизначеність перспектив та принципів взаємовідносин України та ЄС. Перспективи подальших наукових досліджень полягають саме в сфері розбудови плідної співпраці між освітянами України та ЄС в рамках так званого постболонського процесу.

\section{Список посилань}

1. Про невідкладні заходи щодо запровадження зовнішнього незалежного оцінювання та моніторингу якості освіти / Постанова Кабінету Міністрів України від 31 грудня 2005 р. N 1312 [Електронний ресурс]. - Режим доступу: http://zakon2.rada. gov. ua/laws/show/1312-2005-\%Do\%BF

2. Зовнішнє незалежне оцінювання в освіті України. Курс лекцій: навч. посіб. / Г. С. Кашина, В. П. Сергієнко. Луцьк, 2010. 115 с.

3. Про додаткові заходи щодо підвищення якості освіти в Україні / Указ Президента України від 20.03.2008 № 244/2008 [Електронний ресурс]. - Режим доступу: http://zakon2.rada. gov. ua/laws/show/244/2008

4. Інтеграція в європейський освітній простір: здобутки, проблеми, перспективи: Монографія / За заг. ред. Ф. Г. Ващука. Ужгород: ЗакДУ, 2011. 560 с.

5. Закон України Про ратифікацію Конвенції про визнання кваліфікацій з вищої освіти в Європейському регіоні від 03.12.1999 № 1273XIV. Відомості Верховної Ради України (ВВР). 1999. № 51. Ст. 459.

6. Андрущенко В.П. Філософія освіти в постболонському просторі. Вища освіта України. 2006. № 1. С. 5-6.

7. Андрущенко В.П. Вища освіта в пост-Болонському просторі: спроба прогностичного аналізу. Філософія освіти. Київ: Майстерклас. 2005. №2. С. 6-19.

8. Згуровський М.З. Болонський процес: головні принципи та шляхи структурного реформування вищої освіти України. Київ: Видво НТУУ «КПІ», 2006. 544 с.

9. Вища освіта: європейський вимір та українські перспективи: Матеріали слухань у Комітеті Верховної Ради України з питань науки і освіти 18 червня 2008 року. Київ: Парламентське видавництво, 2009 [Електронний ресурс]. - Режим доступу: http://kno. rada. gov. ua/komosviti/control/uk/publish/ article;jsessionid $=6066$ A0400FAB1E84E9959C9F73C24540?art_id=48987\&cat_id=45821 


\section{References}

1. On urgent measures to implement external independent evaluation and monitoring of the quality of education / Resolution of the Cabinet of Ministers of Ukraine of December 31, 2005 N 1312 [Electronic resource].-Access mode: http://zakon2.rada. gov. ua/laws/ show/1312-2005-\%Do\%BF

2. External independent evaluation in education of Ukraine. Course of lectures: textbook. way (2010). / G.S. Kashina, VP Sergienko. Lutsk, 115 p.

3. On additional measures to improve the quality of education in Ukraine / Decree of the President of Ukraine of 20.03.2008 № 244/2008 [Electronic resource]. - Access mode: http://zakon2.rada. gov. ua/ laws/show/244/2008

4. Integration into the European education space: achievements, probiems, prospects: Monograph / Edited by F.G.Vashcuk. Uzhhorod. 560 s.

5. Law of Ukraine On Ratification of the Convention on the Recognition of Qualifications concerning Higher Education in the European Region of December 3, 1999 № 1273-XIV (1999). Bulletin of the Verkhovna Rada of Ukraine (VVR). № 51. P.459.

6. Andrushchenko V.P. (2006). Philosophy of education in the postBologna space. Higher education of Ukraine. № 1. P. 5-6.

7. Andrushchenko V.P. Higher education in the post-Bologna space: an attempt at prognostic analysis. Philosophy of Education. Kyiv: Master class. 2005. №2. P. 6-19.

8. Zhurovskyy M. Z. (2006). Bolonskyy protses: holovni pryntsypy ta shlyakhy strukturnoho reformuvannya vyshchoyi osvity Ukrayiny. Kyiv: Vyd-vo NTUU «KPI». 544 s.

9. Vyshcha osvita: yevropeyskyy vymir ta ukrayinski perspektyvy: Materialyslukhanu KomitetiVerkhovnoyiRadyUkrayinyzpytannauky i osvity 18 chervnya 2008 roku. Kyiv: Parlament•ske vydavnytstvo, 2009 [Elektronnyy resurs]. - Rezhym dostupu: http://kno. rada. gov. ua/komosviti/control/uk/publish/ article;jsessionid=6066Ao4 ooFAB1E84E9959C9F73C24540?art_id=48987\&cat_id=45821

Стаття надійшла до редакції 12.10.20

(C) Якимчук O.I., 2020 